\title{
Effect of Robusta (Coffea canephora P.) Coffee Cherries Storage after Harvest before Putting Out for Sun Drying on Development of Toxigenic Fungi and the Variation of the Physicochemical Components
}

\author{
Irene Ahou Kouadio $^{{ }^{*}}$, Mathias Kouame Koffi ${ }^{1}$, Mireille Bretin Dosso ${ }^{2}$ \\ ${ }^{1}$ Laboratory of Biochemistry and Food Sciences, UFR Biosciences, University Felix Houphouet-Boigny, Abidjan, Ivory Coast; \\ ${ }^{2}$ Pasteur Institute of Ivory Coast, Abidjan, Cote d'Ivoire. \\ Email: irenekouadio@yahoo.fr, djetoplus@yahoo.fr, mireilledosso@yahoo.fr
}

Received September $28^{\text {th }}, 2013$; revised October $28^{\text {th }}, 2013$; accepted November $5^{\text {th }}, 2013$

Copyright (c) 2014 Irene Ahou Kouadio et al. This is an open access article distributed under the Creative Commons Attribution License, which permits unrestricted use, distribution, and reproduction in any medium, provided the original work is properly cited. In accordance of the Creative Commons Attribution License all Copyrights (c) 2014 are reserved for SCIRP and the owner of the intellectual property Irene Ahou Kouadio et al. All Copyright (c) 2014 are guarded by law and by SCIRP as a guardian.

\section{ABSTRACT}

In this study, the effects of the storage duration of coffee cherries after harvest before putting out for sun drying on the kinetics of drying, fungi development and the variation of physicochemical content were evaluated. The results showed that the longer coffee cherries were stored after harvest before putting out for sun drying, the quicker they dried. Indeed, the drying durations were 19, 16, 12, 10, 7 days respectively for coffee cherries put out for sun drying at the day of harvest, the second, the fourth, the sixth and the eighth day after harvest. However, this storage of the cherries after harvest before putting out for sun drying led to the increasing to the infection of cherries by fungi. Indeed, samples of more contaminated inside were those from the lots of cherries stored 8 days after harvest before putting out for sun drying with $55.55 \%$ of the samples infected with a percentage of infected beans between $10 \%$ and $50 \%$, and $44.45 \%$ of the samples were infected with a percentage of infected beans between $50 \%$ and $100 \%$. Furthermore, those put out for sun drying at the day of harvest were free inside by fungi. Among the fungi isolated, toxigenic species was found. However, no relationship between the frequencies of ochratoxin A producing strains isolated and the storage duration of the cherries after harvest before putting out for sun drying was noted. This storage of the cherries after harvest before putting out for sun drying also led to the acidification of the cherries $(\mathrm{pH}=5.27$ - 3.6) and the degradation of their chlorogenic acids content $(12.58 \%-10.30 \%)$ while for their caffeine content $(2.53 \%-2.55 \%)$. No significant difference was observed about the storage duration of the cherries after harvest before putting out for sun drying.

\section{KEYWORDS}

Coffee Cherries; Fungi; Aspergillus; Toxigenic; Physicochemical Components

\section{Introduction}

Coffee, as many vegetables, is subjected to contamination by microorganisms such as fungi before harvest and during post-harvest treatments [1,2]. The frequency of occurrence of these fungi isolated from coffee cherries has been reported by several authors. Indeed, [3] reported that $A$. niger was the most common species found on coffee cherries (63\%), while the percentage of infection

"Corresponding author. by $A$. carbonarius and A. ochraceus was $6 \%$ and $31 \%$, respectively. The results of [4] showed that $A$. carbonarius was frequently found (50\%), while only $7 \%$ of $A$. ochraceus strains were isolated on coffee cherries. Some of these fungi species are capable of producing mycotoxins. The main mycotoxin found in coffee is Ochratoxin A [5]. It is produced by molds of the genera Penicillium in moderately cold regions and by the genera Aspergillus in tropical regions [6]. These molds capable of 
producing OTA have been isolated from coffee cherries in previous studies. Indeed the results of [3] showed that $3 \%$ of 549 A. niger isolates were able to produce OTA, while $77 \%$ of 54 A. carbonarius isolates and $75 \%$ of 269 A. ochraceusisolates produced this mycotoxin. Those obtained by [7] showed that $100 \%$ of $A$. carbonarius and A. ochraceus strains isolated were potential OTA producers. However, although A. niger was more isolated than A. carbonarius and A. ochraceus, only $2.4 \%$ to $3.8 \%$ of strains tested were capable of producing OTA. The natural occurrence of OTA in green coffee beans has been reported by several authors in concentrations from 0.2 to $360 \mu \mathrm{g} \cdot \mathrm{kg}^{-1}$ [4]. This mycotoxin produced by these toxigenic fungi has been shown to exhibit nephrotoxic, immunosuppressive, teratogenic and carcinogenic properties [8]. The International Agency for Research on Cancer (IARC) has classified OTA as a possible human carcinogen (Group 2B) based on sufficient evidence for carcinogenicity in experimental animal studies and inadequate evidence in humans [9]. In order to avoid an impact of this mycotoxin on human health, a level of 3 $\mu \mathrm{g} \cdot \mathrm{kg}^{-1}$ green coffee was suggested by European Commission to European Union Member States [10]. If a maximum limit for OTA in coffee was to be established, it could affect international trade for producer countries. Therefore, solutions to avoid coffee cherries contamination by OTA must be found. For many years now, it has been clear that the most effective means to prevent contamination of crops by mycotoxins is to avoid growth of mycotoxigenic fungi [11]. Furthermore, this contamination of food fed by fungi leads to the degradation of the nutritional quality. Indeed, [12] has reported that fungi growth reduces all amino acids in diet, particularly lysine and arginine. Most of the times, farmers store coffee cherries for a moment after harvest before putting out for sun drying because of the insufficiency of drying areas. Thus, the present study was carried out to evaluate the effect of the storage of coffee cherries after harvest before putting out for sun drying on the kinetics of their drying, infection by fungi and the variation of the physicochemical components of these cherries in order to contribute to the identification of good post-harvest practices to prevent degradation of the quality of this product.

\section{Material and Methods}

The experimental design was:

1) Harvest of 5 lots of ripe coffee cherries of $60 \mathrm{~kg}$ each.

2) Beginning of the first lot of coffee cherries drying on the day of harvest, while for the 4 other lots, the drying was started respectively the second, the fourth, the sixth and the eighth day after harvest (Figure 1) on concrete of $3 \mathrm{~m}^{2}$.

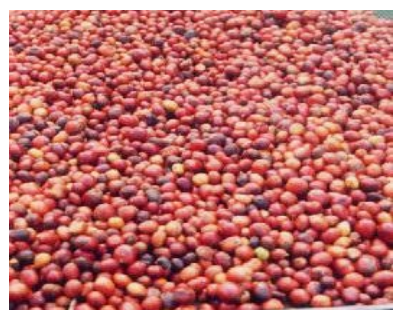

(a)

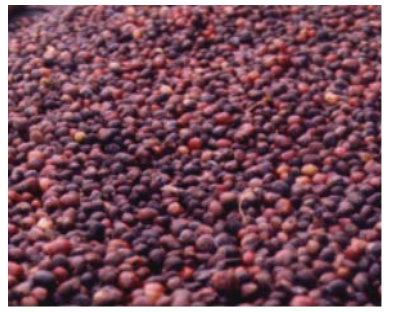

(c)

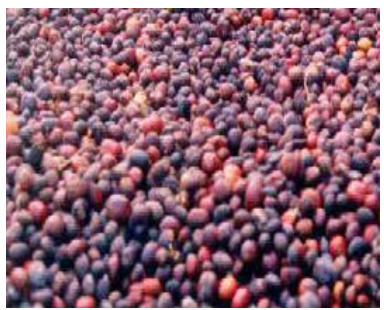

(b)

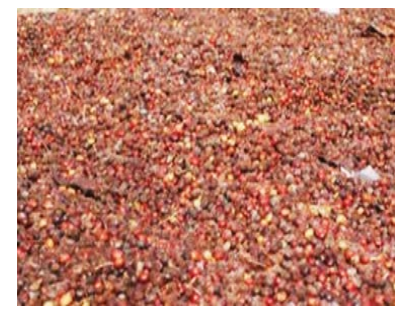

(d)

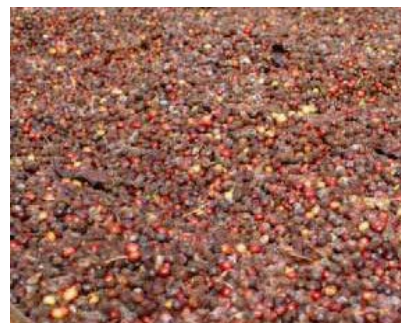

(e)

Figure 1. Coffee cherries the day of harvest: (a) and coffee cherries stored 2 days: (b), 4 days: (c), 6 days: (d) and 8 days: (e) after harvest.

3) Mixing frequency of the 5 lots of coffee cherries was six a day.

4) Sampling: three samples of coffee cherries of $500 \mathrm{~g}$ each were taken from the beginning to the end of drying.

5) Study of the kinetics of drying.

6) Fungal isolation.

7) Test for Ochratoxin A production by isolated fungi.

8) Physicochemical analysis.

\subsection{Material}

Coffee

In this study, ripe Robusta (Coffea canephora P.) coffee cherries from Ivory Coast were used. These coffee cherries were harvested by manual picking in the experimental farm of the National Agronomical Research Center of Divo (Ivory Coast).

\subsection{Methods}

The drying of coffee cherries was made on concrete of 3 $\mathrm{m}^{2}$ which is the drying area most used in Ivory Coast. Coffee cherries were covered at night and if there was rain during the day in order to avoid rewetting. Three 
samples of $500 \mathrm{~g}$ from each lot were taken every day during drying until the moisture content of coffee cherries reached between $11 \%$ and $12 \%$.

\subsubsection{Study of the Kinetic of Drying}

The study of the kinetics of drying was carried out by determining the daily moisture content of coffee cherries put out for sun drying. The method used was that of [13]. Coffee cherries were dried in an incubator at $105^{\circ} \mathrm{C}$ until constant weight. In practical terms, a sample of $200 \mathrm{~g}$ of coffee cherries was dried in the incubator at $105^{\circ} \mathrm{C}$ for 48 $\mathrm{h}$ divided into two periods. First, the sample was dried in the incubator for $24 \mathrm{~h}$ and then put in a dessicator at room temperature for $1 \mathrm{~h}$ until it cooled. It was weighed and dried for a second time of $24 \mathrm{~h}$. The humidity evaporated constituted the moisture content of coffee cherries.

\subsubsection{Fungal Isolation}

The research of the fungi on the surface of coffee cherries was done. For this research, 50 cherries were washed in sterile peptone water. The suspension obtained after washing was diluted by putting $1 \mathrm{~mL}$ of this suspension into a test tube that contained $9 \mathrm{~mL}$ sterile distilled water. A $0.1 \mathrm{~mL}$ aliquot of the spore suspension and subsequent dilutions were surface plated onto the medium (Sabouraud Chloramphenicol Agar) as quickly and carefully as possible. Petri dishes were incubated at $30^{\circ} \mathrm{C}$ for 3 days after which any fungi detected were counted. The results were expressed in CFU/cherry.

For the research of fungi in the beans, 50 cherries were washed in a solution of $\mathrm{NaOH}(1 \%)$ and then rinsed with water until the mucilaginous part disappeared. The parchment coffee was surface sterilized in $5 \%$ sodium hypochlorite for $1 \mathrm{~min}$ and washed three times with sterile distilled water. Parchment coffee sterilized was then plated onto the medium into the Petri dishes (10 per plate). Petri dishes were incubated at $30^{\circ} \mathrm{C}$ for 7 days after which any fungi detected were counted. The results were expressed as the percentage of infected beans (\% infection).

\subsubsection{Fungal Identification}

All the molds isolated were sub-cultured on CzapeckDox Agar and identification was performed according to the classification scheme of [14] and [15].

\subsubsection{Test for OTA Production by Isolated Fungi}

The test for OTA production by isolated fungi was carried out by using the method of [16]. All the isolates identified as Aspergillus were grown on yeast extract $15 \%$ sucrose agar at $25^{\circ} \mathrm{C}$ for 7 days. On each medium, three agar plugs were removed from different points of the colony and extracted with $1 \mathrm{~mL}$ methanol. The extracts were filtered and analyzed by high-pressure liquid chromatography (HPLC) with a fluorescence detector FL3000 (excitation wavelength $332 \mathrm{~nm}$, emission wavelength $466 \mathrm{~nm})$. The HPLC column was a C18 Sorbox SB-48 $(5 \mu \mathrm{m}, 4.6 \times 150 \mathrm{~mm})$ (Agitent, USA). A total of $80 \mathrm{~mL}$ of each sample was injected. The mobile phase consisted of acetonitrile/acetic acid $0.2 \%$ (41:59). The flow rate was $1 \mathrm{~mL} \cdot \mathrm{min}^{-1}$. The retention time for the detection of OTA was around 16 min. Confirmation was made through derevitization of OTA in its methyl-ester [17]. The detection limit was $0.0003 \mu \mathrm{g} \cdot \mathrm{g}^{-1}$.

\subsection{5. $\mathrm{pH}$ Determination}

The $\mathrm{pH}$ was determined by a pH-meter E520 MetrohmHerisau after extraction of $10 \mathrm{~g}$ of finely grinded green coffee beans in boiled water. Three measurements of each sample were obtained.

\subsubsection{Chlorogenic Acids and Caffeine Determination} In green coffee beans, caffeine was extracted from water solution by dichloromethane according to the procedures developed by [18]. After caffeine, chlorogenic acids were extracted from green coffee beans by following the method developed by [19]. A chromatography consists of Hewlett Packard with quarternary pump, auto sampler, Shimadz SPD 10A UV-Vis detector and C18 pre-column and $250 \times 4.6 \mathrm{~mm}$ phenomenex Luna 18 (2) column with $5 \mu \mathrm{m}$ pour size. These chlorogenic acids were analyzed according to the elution program described by [19]. For the two chemical components, three measurements of each sample were obtained.

\subsubsection{Standard Solution Preparations}

For the standard solutions preparation, a commercially bought CGA were dissolved in polar-solvent (ethanol). The solution was uniformly dissolved using magnetic stirrer, and absorbance measured immediately after stirring. Moreover to avoid from light interaction, it was stirred in dark room.

\subsection{Statistical Analysis}

The statistical analysis of data was done by Analysis of Variance (ANOVA) using 5\% level of significance. The statistical package used is IBM SPSS Statistics version 20.

\section{Results}

The study of the kinetic of drying showed that the longer coffee cherries were stored after harvest before putting out for sun drying, the quicker they dried (Figure 2). The drying duration was influenced significantly by the dura- 
tion of the storage of the cherries after harvest before sun drying $(\mathrm{P}<0.05)$ (Table 1). Indeed, the moisture content of the cherries which was $62 \%$ was decreased to reach the values between $11 \%$ and $12 \%$ in $19,16,12,10,7$ days respectively for coffee cherries put out for sun drying the day of harvest, the second, the fourth, the sixth and the eighth day after harvest. Furthermore, the longer coffee cherries were stored after harvest before putting out for sun drying, the more they were infected by fungi (Figure 3). Indeed, all the samples from the lot of coffee cherries put out for sun drying the day of harvest were infected on surface by total molds count between 1000 and 10,000 CFU/cherry, while those more contaminated were cherries stored at least 6 days after harvest before sun drying with a total molds count above 100,000 $\mathrm{CFU} /$ cherry. The identification of fungi isolated on the surface of coffee cherries showed (Table 2) that A. niger was the most common species found $(60 \%-63 \%)$. In addition to A. niger, A. cabonarius (12\% - 25\%), A. ochraceus $(2.7 \%-4.5 \%)$, A. fumigates $(3.5 \%-7.4 \%), A$. flavus $(1.7 \%-4.2 \%)$, A. clavatus $(1.3 \%-3.6 \%)$, A. japonicas $(0.4 \%-5.1 \%)$ and $A$. candidus $(1 \%-2.8 \%)$ were isolated. Other molds $(0.6 \%-1.4 \%)$ and yeast $(0.6 \%$ $9.4 \%)$ were also isolated. The identification of the toxigenic strains done by comparing the HPLC chromatograms obtained with these strains to that of the OTA standard (Figure 4) showed that among these fungi isolated, only A. niger, A. cabonarius, A. ochraceus were capable of producing OTA. However, although A. niger was the most species isolated, only $2 \%$ to $8.5 \%$ were OTA producers, while for A. cabonarius, A. ochraceus, all the strains isolated were OTA producers (Table 3 ).

The fungi were also found inside the cherries. It was noted that the longer coffee cherries were stored after harvest before putting out for drying, the more these cherries were infected inside (Figure 5). Indeed, the cherries put out for sun drying the day of harvest were all free of fungi. For those stored 2 days after harvest before putting out for sun drying, $18 \%$ of the samples were infected with a percentage of infected beans less than $10 \%$, while $82 \%$ were free of fungi. Samples from the lots of cherries stored at least 4 days after harvest before putting out for sun drying were all infected inside. Indeed, for the lot of cherries stored 4 days after harvest, 34.61\% were infected with a percentage of infected beans less than $10 \%$, while $65.39 \%$ were infected with a percentage of infected beans between $10 \%$ and $50 \%$. For the lot of cherries stored 6 days after harvest, 73.36\% and 23.64\%

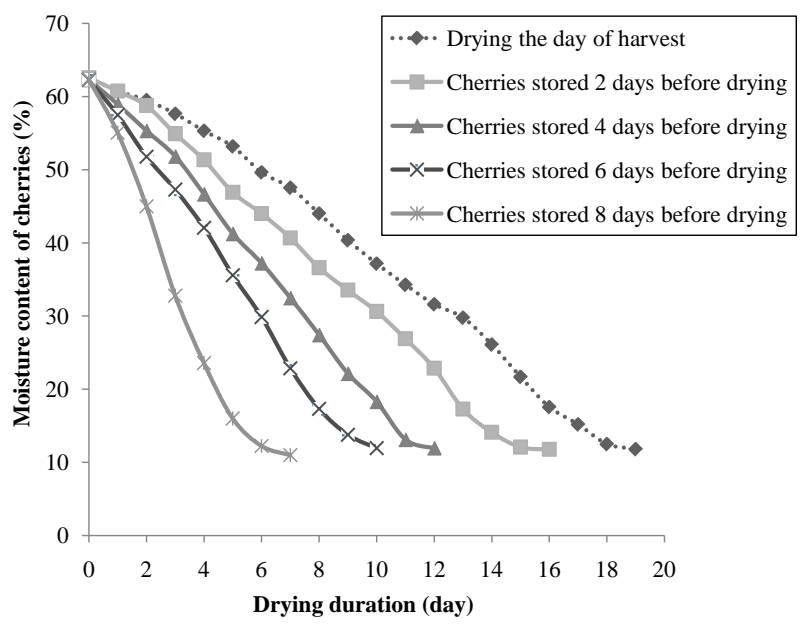

Figure 2. Effect of coffee cherries storage after harvest before putting out for sun drying on drying duration.

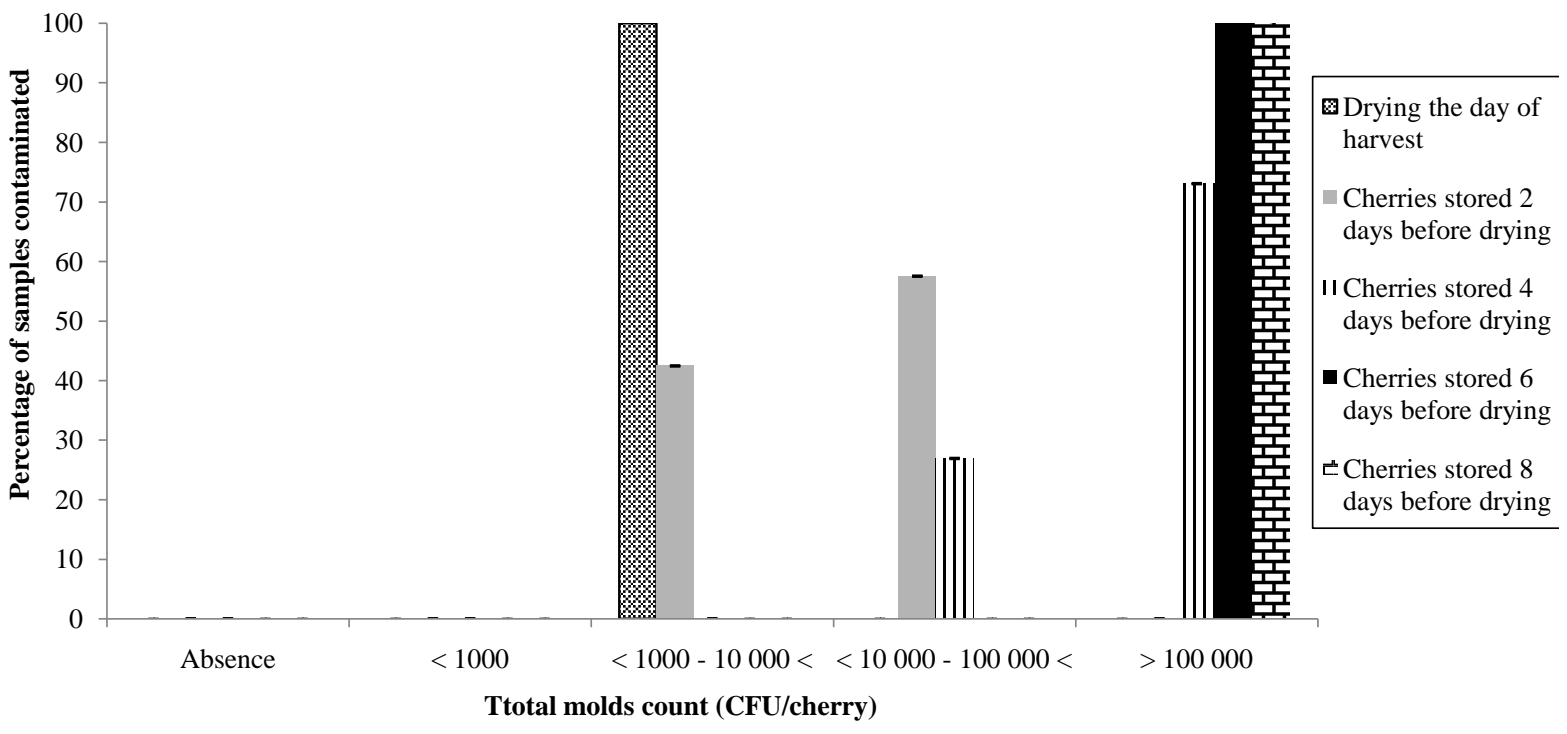

Figure 3. Effect of coffee cherries storage after harvest before putting out for sun drying on fungal development on the surface of coffee cherries. 
Effect of Robusta (Coffea canephora P.) Coffee Cherries Storage after Harvest before Putting Out for Sun Drying on Development of Toxigenic Fungi and the Variation of the Physicochemical Components

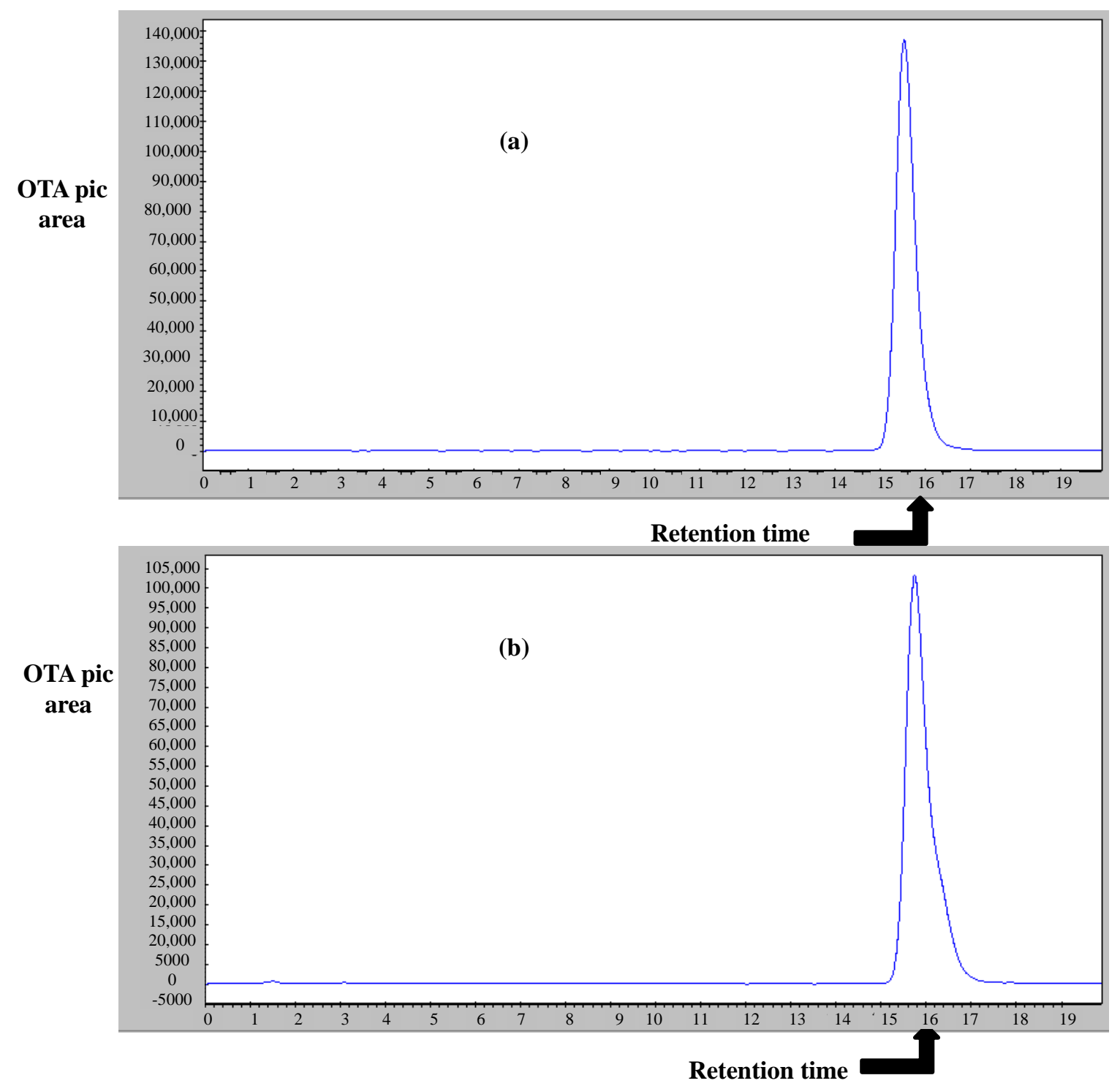

Figure 4. Chromatograms of standard OTA at (a): $0.07 \mu \mathrm{g} / \mathrm{mL}$ and (b): $0.05 \mu \mathrm{g} / \mathrm{mL}$.

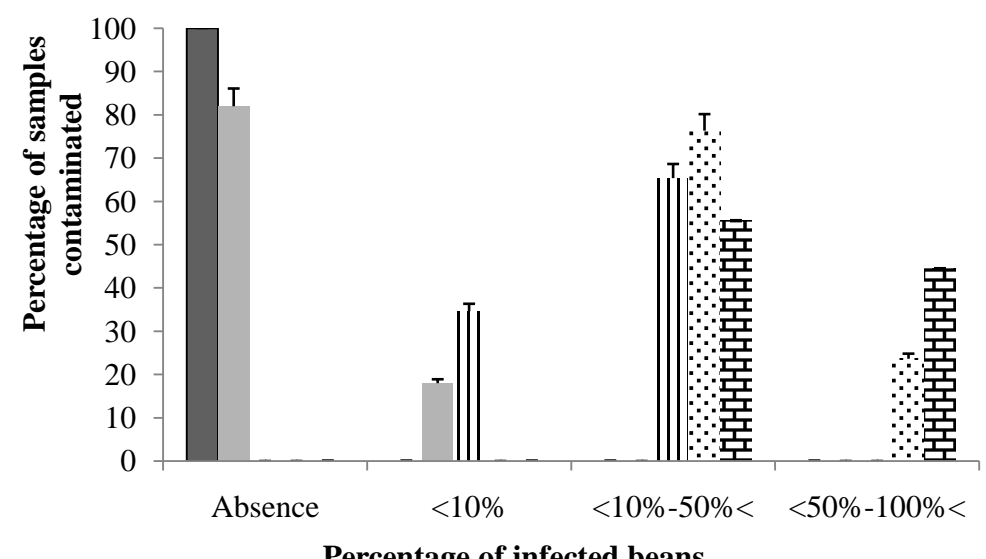

$\square$ Drying the day of harvest

Cherries stored 2 days before drying II Cherries stored 4 days before drying $\because$ Cherries stored 6 days before drying

e Cherries stored 8 days before drying

\section{Percentage of infected beans}

Figure 5. Effect of coffee cherries storage after harvest before putting out for sun drying on fungal development inside of coffee cherries. 
Table 1. Time dependent effect of coffee cherries storage after harvest before putting out for sun drying on drying duration.

\begin{tabular}{ccc}
\hline Storage duration of coffee cherries after harvest before sun drying (day) & Drying duration mean (day) \\
\hline 0 & $19^{\mathrm{e}}$ & $16^{\mathrm{d}}$ \\
2 & $12^{\mathrm{c}}$ \\
4 & $10^{\mathrm{b}}$ \\
8 & $7^{\mathrm{a}}$ \\
\hline
\end{tabular}

Drying times with differential phabetic superscript letters are significantly different at significance level $\alpha=0.05$. The mean of drying duration is significant at the 0.05 level.

Table 2. Effect of coffee cherries storage after harvest before putting out for sun drying on the frequency of fungi species isolated on the surface of the coffee.

\begin{tabular}{|c|c|c|c|c|c|c|c|c|c|c|c|}
\hline \multirow[b]{2}{*}{$\begin{array}{l}\text { Storage } \\
\text { duration of } \\
\text { the fresh } \\
\text { cherries } \\
\text { before sun } \\
\text { drying (day) }\end{array}$} & \multirow[b]{2}{*}{$\begin{array}{c}\text { Number } \\
\text { of } \\
\text { strains } \\
\text { isolated }\end{array}$} & \multicolumn{10}{|c|}{ Fungi species isolated (\%) } \\
\hline & & $\begin{array}{c}A . \\
\text { niger }\end{array}$ & $\begin{array}{c}\text { A. } \\
\text { carbonarius }\end{array}$ & $\begin{array}{c}\text { A. } \\
\text { ochraceus }\end{array}$ & $\begin{array}{c}A . \\
\text { fumigatus }\end{array}$ & $\begin{array}{c}\text { A. } \\
\text { clavatus }\end{array}$ & $\begin{array}{c}A . \\
\text { japonicus }\end{array}$ & $\begin{array}{c}\text { A. } \\
\text { flavus }\end{array}$ & $\begin{array}{c}\text { A. } \\
\text { candidus }\end{array}$ & $\begin{array}{l}\text { Other } \\
\text { molds }\end{array}$ & yeasts \\
\hline 0 & 1122 & 61.9 & 12 & 2.9 & 7.4 & 3.2 & 5.1 & 3.4 & 2.1 & 1.4 & 0.6 \\
\hline 2 & 1414 & 64.2 & 14.3 & 2.7 & 5 & 2.2 & 3.3 & 4.2 & 2 & 1.4 & 0.7 \\
\hline 4 & 1879 & 61 & 21.2 & 4.2 & 4 & 3.6 & 1 & 2.6 & 1 & 1 & 9.4 \\
\hline 6 & 2378 & 60 & 22 & 4.3 & 6 & 1.3 & 0.4 & 2.6 & 2.8 & 0.6 & 0 \\
\hline 8 & 3025 & 63 & 25 & 4.5 & 3.5 & 0 & 0 & 1.7 & 1.3 & 1 & 0 \\
\hline
\end{tabular}

Table 3. Effect of coffee cherries storage after harvest before putting out for sun drying on the frequency of Aspergillus species capable of producing OTA isolated on the surface of the coffee cherries.

\begin{tabular}{ccccccc}
\hline & \multicolumn{5}{c}{ Percentage of strains Ochratoxin A producers } \\
\hline $\begin{array}{c}\text { Storage duration of the fresh } \\
\text { cherries before sun drying (day) }\end{array}$ & A. niger & A. carbonarius & A. ochraceus & A. fumigatus & A. flavus & A. candidus \\
\hline 0 & 6.7 & 100 & 100 & 0 & 0 & 0 \\
2 & 2.0 & 100 & 100 & 0 & 0 & 0 \\
4 & 3.0 & 100 & 100 & 0 & 0 & 0 \\
6 & 2.8 & 100 & 100 & 0 & 0 & 0 \\
\hline
\end{tabular}

of the samples were infected respectively with a percentage of infected beans between $10 \%$ and $50 \%$ and between $50 \%$ and $100 \%$. The samples from the lot of cherries stored 8 days after harvest before putting out for sun drying could also be divided into 2 lots of samples. Indeed, $55.55 \%$ of the samples from this lot were infected with a percentage of infected beans between $10 \%$ and $50 \%$ while $44.45 \%$ were infected with a percentage of infected beans between $50 \%$ and $100 \%$. The identification of fungi isolated inside the coffee cherries has also shown that the most common species found were A. niger (34.5\% $55 \%)$. It was also noted that $A$. cabonarius (20\% - 25\%),
A. ochraceus (4.1\% - 14.7\%), A. fumigatus (4\% - 19.1\%), A. flavus (3\% - 5.2\%), and A. japonicus (3.5\% - 11.9\%) were isolated. Other molds $(1.1 \%-4.1 \%)$ and yeasts (2.3\% - 3\%) were also isolated (Table 4).

The test for OTA production by fungi isolated from the interior of coffee cherries also showed that only strains of $A$. niger, A. carbonarius and A. ochraceuswere capable of producing OTA (Table 5).

All the strains of $A$. cabonarius and A. ochraceus isolated were potential OTA producers. However, although A. niger was more isolated than $A$. cabonarius and $A$. ochraceus, only $3 \%$ to $5.6 \%$ of strains tested were capa- 
ble of producing OTA.

The evaluation of the physicochemical components showed an acidification (Table 6$)$ of the cherries $(\mathrm{pH}=$ 5.27 - 3.6) and the degradation of the chlorogenic acids content $(12.58 \%$ - 10.30\%) with the increasing of the storage duration of the cherries before drying (Table 7). However, for the caffeine content (2.53\% - 2.55\%), no significant difference was observed (Table 8) whatever the storage duration of coffee cherries before putting out for sun drying ( $p>0.05)$.

Table 4. Effect of coffee cherries storage after harvest before putting out for sun drying on the frequency of fungi species isolated inside of the coffee cherries.

\begin{tabular}{|c|c|c|c|c|c|c|c|c|c|}
\hline \multirow[b]{2}{*}{$\begin{array}{l}\text { Storage duration of the fresh } \\
\text { cherries before sun drying (day) }\end{array}$} & \multirow[b]{2}{*}{$\begin{array}{c}\text { Number of } \\
\text { strains isolated }\end{array}$} & \multicolumn{8}{|c|}{ Fungi species isolated (\%) } \\
\hline & & A. niger & $\begin{array}{c}\text { A. } \\
\text { carbonarius }\end{array}$ & A. ochraceus & A. fumigatus & A. japonicus & $\begin{array}{l}\text { A. } \\
\text { flavus }\end{array}$ & $\begin{array}{l}\text { Other } \\
\text { molds }\end{array}$ & Yeasts \\
\hline 0 & 0 & 0 & 0 & 0 & 0 & 0 & 0 & 0 & 0 \\
\hline 2 & 99 & 50.9 & 20.4 & 4.1 & 11.7 & 3.9 & 3 & 4.1 & 2.3 \\
\hline 4 & 393 & 34.5 & 20 & 9.3 & 19.1 & 11.9 & 5.2 & 0 & 0 \\
\hline 6 & 613 & 39.8 & 27.3 & 14.7 & 10.2 & 3.5 & 3.4 & 1.1 & 0 \\
\hline 8 & 815 & 55 & 25 & 8 & 4 & 3.5 & 0 & 1.5 & 3 \\
\hline
\end{tabular}

Table 5. Effect of coffee cherries storage after harvest before putting out for sun drying on the frequency of Aspergillus species capable of producing OTA isolated inside of the coffee cherries.

\begin{tabular}{|c|c|c|c|c|c|c|}
\hline \multirow[b]{2}{*}{$\begin{array}{l}\text { Storage duration of the fresh cherries } \\
\text { before sun drying (day) }\end{array}$} & \multicolumn{6}{|c|}{ Percentage of strains Ochratoxin A producers } \\
\hline & A. niger & A. carbonarius & A. ochraceus & A. fumigatus & A. japonicus & A. flavus \\
\hline 0 & 0 & 0 & 0 & 0 & 0 & 0 \\
\hline 2 & 3 & 100 & 100 & 0 & 0 & 0 \\
\hline 6 & 3.4 & 100 & 100 & 0 & 0 & 0 \\
\hline 8 & 5.6 & 100 & 100 & 0 & 0 & 0 \\
\hline
\end{tabular}

Table 6. Effect of coffee cherries storage after harvest before putting out for sun drying on pH variation.

\begin{tabular}{ccc}
\hline Storage duration of the fresh cherries before sun drying (day) & Mean of $\mathbf{p H}$ & Coffee cherries $\mathbf{p H}$ variation during sun drying \\
\hline 0 & $5.27 \pm 0.35$ & $4.90-5.70$ \\
2 & $5.20 \pm 0.34$ & $4.70-5.60$ \\
4 & $4.30 \pm 0.39$ & $3.80-4.90$ \\
6 & $4.00 \pm 0.38$ & $3.6-4.50$ \\
8 & $3.6 \pm 0.40$ & $3.30-4.20$ \\
\hline
\end{tabular}

Table 7. Effect of coffee cherries storage after harvest before putting out for sun drying on variation of chlorogenic acids content.

\begin{tabular}{ccc}
\hline $\begin{array}{c}\text { Storage duration of the fresh cherries } \\
\text { before sun drying (day) }\end{array}$ & $\begin{array}{c}\text { Mean of chlorogenic acids content (\%) } \\
0\end{array}$ & $\begin{array}{c}\text { Variation of chlorogenic acids content } \\
\text { during sun drying (\%) }\end{array}$ \\
\hline 2 & $12.58 \pm 0.43$ & $12.10-13.20$ \\
4 & $10.65 \pm 0.40$ & $13.80-10$ \\
6 & $10.62 \pm 0.46$ & $10.20-1.40$ \\
8 & $10.30 \pm 0.50$ & $9.30-11.00$ \\
\hline
\end{tabular}


Table 8. Effect of coffee cherries storage after harvest before putting out for sun drying on variation of caffeine content.

\begin{tabular}{ccc}
\hline $\begin{array}{c}\text { Storage duration of the fresh cherries } \\
\text { before sun drying (day) }\end{array}$ & Mean of caffeine (\%) & $\begin{array}{c}\text { Coffee cherries caffeine variation during } \\
\text { sun drying (\%) }\end{array}$ \\
\hline 0 & $2.53 \pm 0.01$ & $2.52-2.55$ \\
2 & $2.53 \pm 0.01$ & $2.52-2.54$ \\
4 & $2.54 \pm 0.03$ & $2.53-2.56$ \\
6 & $2.53 \pm 0.04$ & $2.51-2.55$ \\
8 & $2.55 \pm 0.04$ & $2.50-2.70$ \\
\hline
\end{tabular}

\section{Discussion}

This study has confirmed the effect of post-harvest practices on coffee quality. The rapidity of drying observed when coffee cherries were stored for a long time after harvest before putting out for drying could be explained by the fact that fresh cherries with their high moisture content fermented during storage prior the beginning of the drying. This fermentation makes fragile the pericarp covering the cherry. The pericarp becomes more permeable. The permeability of the pericarp promotes rapid evaporation of the water contained in these cherries during drying. The team of [20] had also shown that the high moisture content favored the fermentation of coffee during storage. Other previous works including those of [21-23], showed that prolongation of coffee cherries storage before drying led to their fermentation. This fermentation of the coffee cherries led also to the proliferation of fungi on the surface of the cherries. This could be explained by the fact that, during the fermentation of the cherries, the activity of the fungi increases. These results confirmed those obtained previously by [20-23]. These fungi were also found inside the coffee cherries the longer these cherries were stored after harvest before putting out for sun drying. This could be explained by the fact that the fermentation of the cherries observed when the cherries were stored after harvest before the drying led to the degradation of the pericarp of these cherries promoting the infection of the beans. As the cherries put out for sun drying the day of harvest were inside free of fungi, the beginning of the drying must start the day of harvest to avoid coffee beans infection.

The identification of the fungi isolated on the surface and inside the cherries showed that $A$. niger was the most common species isolated. These results confirmed those of $[1,3,24]$. Previous studies showed that $A$. niger is known to be widely distributed in the environment [25]. These authors had also shown that this species was more prevalent in warmer climates. This fact explained why it was more isolated on the surface and inside the coffee cherries harvested in the tropical region used in the present study. It was also noted that Aspergillus species were fungi more found on the surface and also inside the coffee cherries. This confirmed results of [26].

The test for OTA production by isolated fungi showed that among the Aspergillus species isolated, only strains of A. niger, A. carbonarius and A. ochraceus were capable of producing this mycotoxin. All the strains of $A$. carbonarius and $A$. ochraceus were capable of producing OTA. However, although A. niger was the most common species found on the surface and also inside the coffee cherries, only occasional strains of this specie were potential OTA producers. These results confirmed those of [3,27].

It can be concluded that the presence of this species in coffee gives little indication of OTA contamination, while infection of coffee beans by A. carbonarius and $A$. ochraceus presents a risk of contamination by this mycotoxin.

It was also noted that the cherries more infected by fungi become acid. This acidification is due to the fermentation of the coffee cherries during their storage after harvest before putting out for sun drying. These results confirm those obtained by $[28,29]$ who showed that fermentation of coffee cherries led to their acidification. The degradation of the chlorogenic acids content of the cherries was also noted the longer these cherries were stored after harvest before putting out for sun drying. However, this storage of the coffee cherries after harvest before putting out for sun drying had no effect on the caffeine content of this product.

\section{Conclusion}

The present study has shown that the storage of coffee cherries after harvest before putting out for sun drying is most likely one of the main parameters contributing to infection of beans by fungi among which toxigenic species were found. However, no relationship between the frequencies of Ochratoxin A producing strains isolated and the storage duration of the cherries after harvest before putting out for sun drying was noted. This storage of the cherries before sun drying also led to their acidification. Thus, for the preservation of the hygienic and sensorial quality of this product, the drying of coffee cherries must start from the day of harvest. 


\section{Acknowledgements}

The authors gratefully acknowledge the laboratory of Mycology of Pasteur Institute of Cocody-Abidjan (Ivory Coast) for the identification of the fungi isolated in this study. The authors gratefully acknowledge also the laboratory of Biochemistry and food Sciences, University of Felix Houphouet-Boigny for the fund.

\section{REFERENCES}

[1] P. B. Mislivec, V. R. Bruce and R. Gibson, "Incidence of Toxigenic and Others Molds in Green Coffee Beans," Journal of Food Protection, Vol. 46, 1983, pp. 969-973.

[2] C. F. Silva, R. F. Schwan, E. Sousa-Diaz and A. E. Wheals, "Microbial Diversity during Maturation and Natural Processing of Coffee Cherries of Coffea arabica in Brazil," International Journal of Food Microbiology, Vol. 60, No. 2-3, 2000, pp. 251-260. http://dx.doi.org/10.1016/S0168-1605(00)00315-9

[3] M. H. Taniwaki, J. I. Pitt, A. A. Teixeira and B. T. Iamanaka, "The Source of Ochratoxin A in Brazilian Coffee and Its Formation in Relation to Process Methods," International Journal of Food Microbiology, Vol. 82, No. 2, 2003, pp. 173-179. http://dx.doi.org/10.1016/S0168-1605(02)00310-0

[4] H. M. L. J. Joosten, J. Goetz, A. Pittet, M. Schellenberg and P. Bucheli, "Production of Ochratoxin A by Aspergillus carbonarius in Coffee Cherries," International Journal of Food Microbiology, Vol. 65, No. 1-2, 2001, pp. 39-44. http://dx.doi.org/10.1016/S0168-1605(00)00506-7

[5] J. Le-Bars and P. Le-Bars, "Mycotoxigenesis in Grains. Application to Mycotoxic Prevention in Coffee. Coffee Biotechnology and Quality,” Kluwer Academic Publishers, Sera, 2000, pp. 355-368.

[6] J. Varga, E. Kevel, E. Rinyu, J. Téren and Z. Kozakiewicz, “Ochratoxin Production by Aspergillus Species," Applied and Environmental Microbiology, Vol. 62, No. 12, 1996, pp. 4461-4464.

[7] I. A. Kouadio, L. B. Koffi, J. G. Nemlin and M. B. Dosso, "Effect of Robusta (Coffeacanephora P.) Coffee Cherries Quantity Put Out for Sun Drying on Contamination by Fungi and Ochratoxin A (OTA) under Tropical Humid Zone (Côte d'Ivoire)," Food and Chemical Toxicology, Vol. 50, No. 6, 2012, pp. 1969-1979. http://dx.doi.org/10.1016/j.fct.2012.03.042

[8] A. Pfohl-Leszkowiz and M. Castegnaro, "L'ochratoxine A,” In: A. Pfohl-Leszkowiz, Ed., Les Mycotoxines dans L'Alimentation: Evolution et Gestion des Risques, Lavoisier, Paris, 1999, pp. 249-277.

[9] International Agency for Research on Cancer, "Monograph on the Evaluation of Carcinogenic Risk to Humans: Some Naturally Occurring Substances, Some Foodstuffs and Constituents, Heterocyclic Aromatic Amines and Mycotoxins,” IARC Monograph, Vol. 56, 1993, pp. 489-521.

[10] S. Romani, G. Sachetti, C. C. López, G. G. Pinnavia and M. D. Rosa, "Screening on the Occurrence of Chratoxin A in Green Coffee Beans of Different Origins Types,”
Journal of Agricultural and Food Chemistry, Vol. 48, No. 8, 2000, pp. 3616-3619. http://dx.doi.org/10.1021/jf990783b

[11] L. B. Bullerman, "Incidence and Control of Mycotoxins Producing Molds in Domestic and Imported Cheeses," Annals of Nutrition and Food, Vol. 31, 1977, pp. 435446.

[12] M. V. L. N. Raju and R. S. V. Rao, "Aflatoxins in Poultry Diet: Natural Ways for Counteraction," Proceedings of Annual Conference, Compound Livestock Feed Manufacturers Association, Mumbai, 13-14 September 2004.

[13] P. Mazzafera, "Chemical Composition of Defected Coffee Beans,” Food Chemistry, Vol. 64, No. 4, 1999, pp. 547554. http://dx.doi.org/10.1016/S0308-8146(98)00167-8

[14] K. B. Raper and D. I. Fennel, "The Genus Aspergillus," Williams \& Wilkins, Baltimore, 1965.

[15] R. A. Samson, E. S. Hoekstra, J. C. Frisval and O. Filtenborg, "Introduction to Food Borne Fungi," Central Bureau Voor Schimmelcultures Bararn, Delft, 1995, p. 322.

[16] M. R. Bragulat, M. L. Arbaca and F. J. Cabañes, “An Easy Screening Method for Fungi Producing OTA in Pure Culture,” International Food Microbiology, Vol. 71, No. 2-3, 2001, pp. 139-144. http://dx.doi.org/10.1016/S0168-1605(01)00581-5

[17] D. C. Hunt, L. A. Philip and N. T. Crosby, "Determination of Ochratoxin A in Pig's Kidney Using Enzymatic Digestion, Dialysis and HPLC with Post-Column Derivatisation,” 1979.

[18] A. Belay, K. Ture, M. Redi and A. Asfaw, "Measurement of Caffeine in Coffee Beans with UV-V Is Spectrometer," Food Chemistry, Vol. 108, No. 1, 2008, pp. 310-315. http://dx.doi.org/10.1016/j.foodchem.2007.10.024

[19] C. L. Ky, M. Noirt and S. Hamon, "Comparison of Five Purification Methods for Chlorogenic Acids in Green Coffee Beans," Journal of Agriculture and Food Chemistry, Vol. 45, No. 3, 1997, pp. 786-790. http://dx.doi.org/10.1021/jf9605254

[20] A. Illy and R. Viani, "Expresso Coffee: The Chemistry of Quality,” Academic Press, Sao Diego, 1996, p. 253.

[21] J. C. Vincent, M. Brecl and F. Challot, "Contribution à L'étude des Fèves Défectueuses du Café Vert,” $7^{\mathrm{e}}$ Colloque, ASIC Paris, Hambourg, 1975, pp. 133-140.

[22] E. Cros, B. Guyot and J. C. Vincent, "Profil Chromatographique de la Fraction Volatile du Café: Différence entre Cafés verts Saint et Puant. Influence de la Torréfaction sur le Grain et la Boisson,” Café, Cacao, Thé, Vol. 23, No. 3, 1979, pp. 193-202.

[23] B. Guyot, E. Cros and J. C. Vincent, "Caractérisation et Identification de la Fraction Volatile d'un Café vert Arabica Saint et d'un Café vert Arabica Puant," Café Cacao Thé, Vol. 26, No. 4, 1982, pp. 279-289.

[24] P. Bucheli, K. Chaorai., I. Meyer and A. Pittet, "Development of Ochratoxin A during Robusta (Coffeacanephora) Coffee Cherries Drying,” Journal of Agricultural and Food Chemistry, Vol. 48, No. 4, 2000, pp. 13581362. http://dx.doi.org/10.1021/jf9905875

[25] J. I. Pitt and C. D. Hocking, "Fungi and Food Spoilage," 
2nd Edition, Aspen Publishers, Gaithersburg, 1997, p. 409. http://dx.doi.org/10.1007/978-1-4615-6391-4

[26] L. R. Batista, S. M. Chalfoun, G. Prado, R. F. Schwan and A. E. Wheals, "Toxigenic Fungi Associated with Processed Green Coffee Beans (Coffeaarabica L.),” International Journal of Food Microbiology, Vol. 85, No. 3, 2003, pp. 293-300. http://dx.doi.org/10.1016/S0168-1605(02)00539-1

[27] C. N. Heenan, K. J. Shaw and J. I. Pitt, "Ochratoxin A Production by Aspergillus carbonarius and Aspergillus- niger Isolates and Detection Using Coconut Cream Agar,” Journal of Food Mycology, Vol. 1, 1998, pp. 67-72.

[28] I. P. Leite, “Influence de la Region de Production et des Techniques de Récolte sur les Caractéristiques Physique, Chimique et Organoleptique du café (Coffea arabica L.)," MsC Thesis, Université Fédérale de Lavras, Lavras, 1991.

[29] S. J. R. Chagas, “Caractéristiques Chimique et Qualitative du Café de Quelques Régions Productrices de Minas Gerais,” MsC Thèse, Université Fédérale de Lavras, Lavras, 1994. 